\title{
Organic Light Emitting Diodes: The Future Display
}

\author{
Jyoti Krayla \\ Under graduate Student \\ EC Department Shri Dadaji \\ Institute of Technology \& Science, \\ Khandwa
}

\begin{abstract}
This paper presents the basic OLED display technology which makes possible to reduce the operating voltage with significant improvement in bright light output and efficiency. This future display technology comprise of tiny dots of organic material or simply polymer that gives radiative emission when charged with electricity. It is the most trustworthy technology for future flat panel displays which makes use of electroluminescence. Future cell phones, laptops, television screen, displays at airport railways will be based on this display technology. Also its efficiency, brightness, flexibility, light weight, fast response time, low manufacturing cost attracts manufactures and scientist to do in field of future display technology i.e. OLED.
\end{abstract}

\section{General Terms}

Display Technology

\section{Keywords}

OLED, Electroluminescence, flat panel display

\section{INTRODUCTION}

OLED was firstly introduced in year 1987, which give attractive luminance or emit light when external voltage is applied. On application of electric field to organic material of OLEDs light is emitted which do not involve any intermediate form of energy, this phenomena is called as organic electroluminescence (EL). OLED based Displays have a plus point over LCDs due to their attractive properties such as fast response time and viewing-angle independence. Today all OLED manufactures make use of evaporation of small organic molecules.

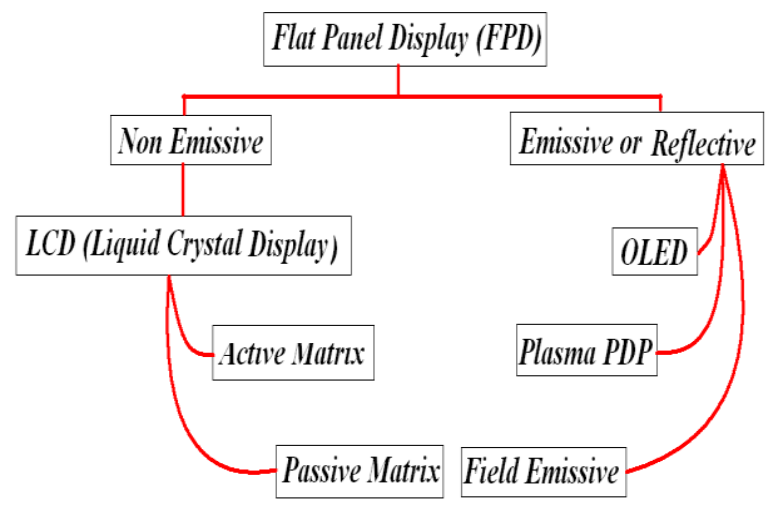

Figure-1 Classification of flat panel display

There are three important processes which govern the effectiveness of the OLED and these are charge injection, charge transport and emission. In OLEDs the color of emitted light can be varied with the variation of organic molecule which means that the color of light totally depends on the type of organic material in emissive layer. In order to get multicolor number of different organic layers is used. The intensity or brightness of the light depends on the amount of electrical current applied. If more current is applied to the OLED, the brighter the light appears. OLED incorporates the advantage of low weight, slimmer, portable, eco friendly, low power consumption, good brightness, good picture quality and fashionable.

\section{CONSTRUCTION}

Mainly OLED is organic LED (light emitting diode) which emits light when external supply is given to it. It consists of very thin and fine film of organic material placed between two conductors like a sandwich structure. Conductive layer is actually 2 or more layers of ETL (electron transport layer) and HTL (hole transport layer).

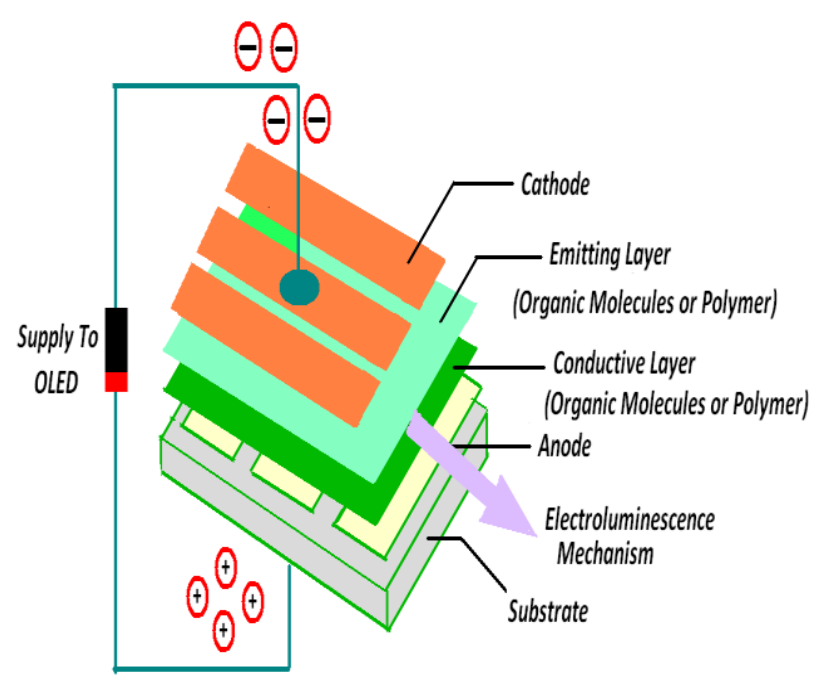

Figure-2 Illustrative Diagram of OLED

OLED mainly comprised of

1) Substrate: It is the supporting material of OLED and it is made up of plastic, foil or sometimes glass.

2) Anode: It is one terminal end of OLED which is kept at positive potential and it is generally made up of indium tin oxide because this material helps injection of holes into the HOMO level of organic material and also it shows transparency to visible light.

3) Cathode: It is kept at negative terminal of OLED. The component of cathode depends on the OLED type. Whereas aluminum, barium and calcium are usually used metals and reason behind their use is that they have lesser work functions than anodes. It is possible to use transparent cathodes too. 
4) Electron Transport layer: As name suggests this layer helps electrons for their motion from molecule to molecule. Commonly used components are PBD, Alq3, TPBI and BCP.

5) Holes transport layer: As name suggests this layer helps holes for their motion from molecule to molecule. Commonly used components in holes transport layer are TPD and NPB.

6) Emissive layer: This layer is composed of organic plastic molecules. As name suggests this layer is emissive that emits or radiates light in form of photon due to decay of the excited state. The frequency of radiation is in visible region and totally depends on the band gap energy. Polyfluorene is the commonly used material.

\section{WORKING OF OLED}

When supply is connected to OLED in such a manner that anode (i.e. indium tin oxide) is at positive potential where as cathode (i.e. metal) is at negative potential. From anode and cathode holes and electrons start injecting into HOMO of HTL and LUMO of ETL respectively.

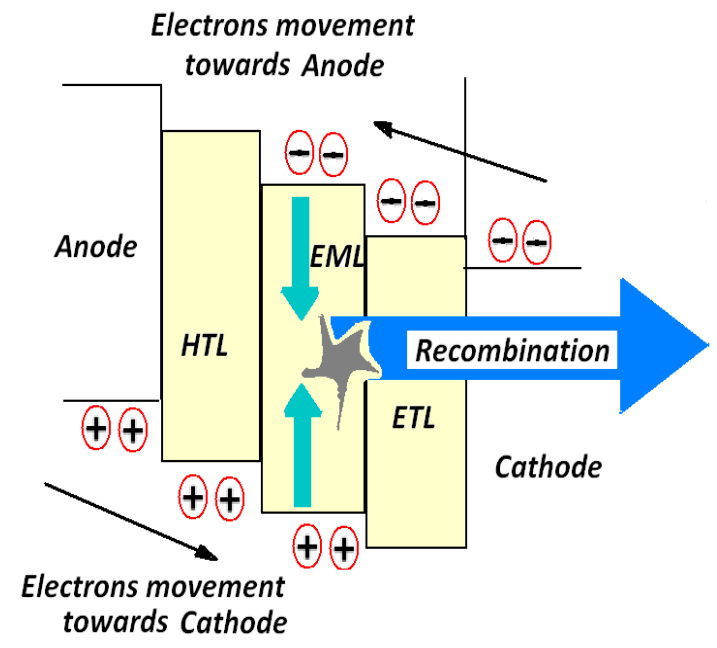

Figure-3 working of OLED, (a) Electrons and holes are injected from the electrodes to the organic emissive layer (EML) (b) Formation of an electron-hole pair or excitation (green) (c) The radiative recombination of this excitation

leads to a photon emission or electroluminescence.

In other words or more simply electrons and holes migrate towards the oppositely charged electrode. The opposite journey of these charge carriers from molecule to other molecule a time will occur when electron and hole localize on the same molecule and they result in form of electron hole pair recombination.

This recombination results in large amount of emission of energy in form of light or photons i.e. radiative emission. It is noted that the thermal emission i.e. non-radiative emission also occurs some time but it is highly undesirable in this case. In OLED's at least one electrode must be transparent or semi transparent in order to make light emission perpendicular to the substrate as shown in figure. This results in very bright display with very less power consumption as compared to conventional LEDs and LCDs.

OLEDs can be classified into Following:

\section{Active matrix OLEDs (AMOLEDs)}

\section{Passive matrix OLEDs (PMOLEDs) \\ 3. Transparent OLEDs (TOLEDs) \\ 4. Foldable OLEDs (FOLEDs) \\ 5. White OLEDs}

Active matrix OLED (AMOLED) contain full layers of anode, cathode and organic molecules where as Passive matrix OLED (PMOLED) contain organic layers and strips of anode arranged perpendicular to the cathode strips. Transparent OLED (TOLEDs) consist of only transparent components i.e., anode, cathode and substrate. TOLEDs have transparency and can be constructed to emit light on both the top as well as bottom side. FOLEDs (foldable OLEDs) as their name suggest are highly flexible OLEDs which have substrate made of very flexible plastics or metallic foils. White OLEDs emits white light that is uniform, energy efficient, more view angle and brightness.

\section{RESULTS}

The significance or future scope of OLED can be clearly understood by following results.

Table: 1 Performance comparison of OLED on basis of layer of organic material

\begin{tabular}{|c|c|c|c|c|}
\hline SNO. & $\begin{array}{c}\text { organic } \\
\text { material } \\
\text { layer }\end{array}$ & $\begin{array}{c}\text { Driving } \\
\text { Voltage }\end{array}$ & $\begin{array}{c}\text { Lumines } \\
\text { cence }\end{array}$ & $\begin{array}{c}\text { Quantum } \\
\text { Efficiency }\end{array}$ \\
\hline 1. & $\begin{array}{c}\text { Single } \\
\text { layer }\end{array}$ & $\begin{array}{c}\text { High } \\
\text { Larger } \\
\text { than } \\
100 \mathrm{~V})\end{array}$ & Low & $\begin{array}{c}\text { Poor } \\
\text { Efficiency }\end{array}$ \\
\hline 2. & $\begin{array}{c}\text { Two } \\
\text { layer of } \\
\text { different } \\
\text { organic } \\
\text { material }\end{array}$ & $\begin{array}{c}\text { Low } \\
(\sim 10 \mathrm{~V})\end{array}$ & High & $\begin{array}{c}\text { Good } \\
\text { Efficiency }\end{array}$ \\
\hline
\end{tabular}

From table 1 it is concluded that with increase in number of layer of organic material the quantum efficiency and luminescence increases where as there is effective decrement in the driven voltage. Also with increment in layers helps OLED in injecting charge carriers with more power at the electrode and this result in blocking the charge from being dumped.

Table: 2 Comparison of a flexible form of LCD and key flexible display technologies

\begin{tabular}{|c|c|c|c|}
\hline Parameter & LCD & OLED & $\begin{array}{c}\text { E-paper } \\
\text { Display }\end{array}$ \\
\hline $\begin{array}{c}\text { Contrast } \\
\text { Ratio }\end{array}$ & $10: 1$ & $>10,000$ & $10: 1$ \\
\hline Colors & 4,096 & $16 \mathrm{~m}$ & $\begin{array}{c}2(\text { future } \\
4,096+)\end{array}$ \\
\hline Pricing & Low & High today & $\begin{array}{c}\text { Low/Medium } \\
\text { today }\end{array}$ \\
\hline $\begin{array}{c}\text { Technology } \\
\text { Barrier }\end{array}$ & Low & $\begin{array}{c}\text { High/med. } \\
\text { Today }\end{array}$ & Low \\
\hline
\end{tabular}


Source: IEK Taiwan, Compiled by Digitimes, July 2007

Table: 3 Comparative analyses between different displays Technologies

\begin{tabular}{|c|c|c|c|c|c|c|}
\hline SNO & Parameters & $\mathbf{C}$ & $\mathbf{L}$ & Plasma & L & O \\
$\cdot$ & & $\mathbf{R}$ & $\mathbf{C}$ & & E & L \\
& & T & D & & D & E \\
& & & & & & D \\
\hline 1 & Brightness & + & + & + & + & o \\
\hline 2 & Response time & + & + & + & + & + \\
\hline 3 & Thickness & - & + & + & + & + \\
\hline 4 & Power & - & + & - & - & + \\
\hline 5 & Consumption & & & & & \\
\hline
\end{tabular}

$+=\operatorname{good} /$ positive

$\mathrm{o}=$ neutral

$-=$ lower performance

Source: Sharp Microelectronics Europe, April 2008

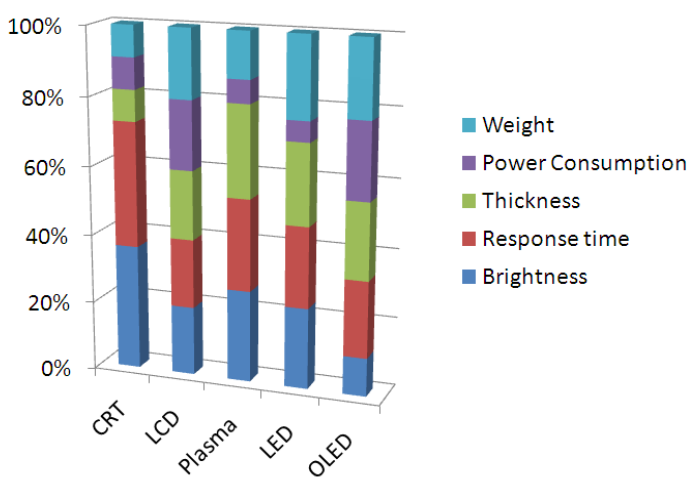

Figure-4 Graph showing comparison between display technologies

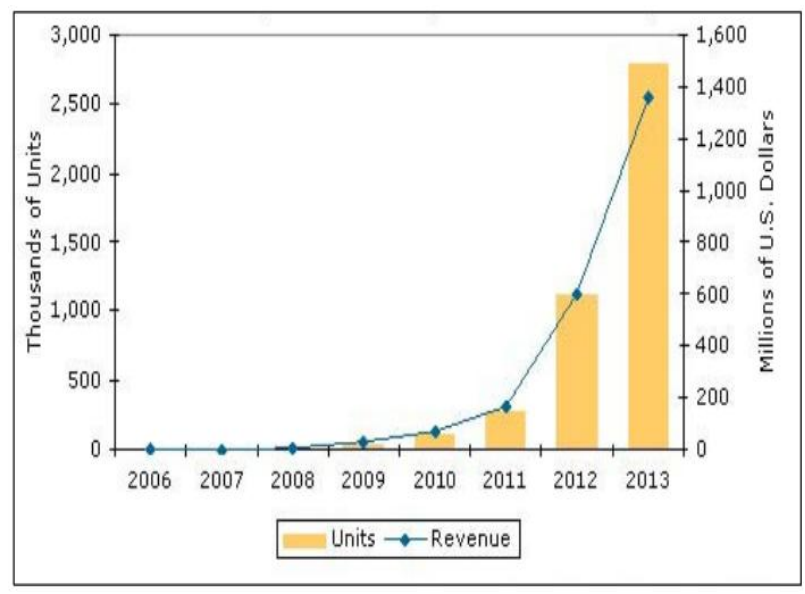

Figure-5 Global OLED TV market Forecast

Source: iSuppli, 2007, as reported by OLED-info.com

\section{CONCLUSION}

OLED can be considered as future display technology because of its flexibility and finds high application in manufacturing of Full HD TV, transparent OLED laptop, lighting lamps, portable devices like cell phones, car lighting, digital media players, car radios and many more. OLED technology will going to prove its significance in four field of development i.e. Optical Engineering, Device Structure, Materials and Electrical Engineering. OLED is considered as toughest competition for all types of displays but there are some challenges too like its sensitivity to water vapors, longevity for some colors like blue color has very short life time. Today OLED display consumes 40 percent of the power of an LCD displaying an image which is primarily black but for the majority of images it will consume 60 to 80 percent of power of an LCD. OLED gives improved image quality, better contrast, fuller viewing angle, wider color range. In mobile applications OLEDs are giving tough competition to LCDs. It is no wonder that in upcoming days OLEDs will be part of not industrial but also our life.

\section{ACKNOWLEDGMENTS}

I would like to acknowledge my faculties of electronics and Communication department SDITS Khandwa (M.P.)

\section{REFERENCES}

[1] Tang, C.2001. 'Brightness on display', OE Magazine, the Monthly Publication of SPIE-The International Society for Optical Engineering, February, pp. 19-21

[2] Smith, P ,2003, 'OLED displays: better than plasma or LCD', Silicon Chip Online

[3] J. Shinar, 2004, Organic Light-emitting Devices, Springer, Berlin.

[4] J. Kalinowski, 2005, Emission Mechanisms in Organic Light-Emitting Diodes, Organic Electroluminescence, Taylor \& Francis, Boca Raton.

[5] J. Malinowski, 2005, Organic Light Emitting Diodes: Principles, .Characteristics and Processes, Marcel Dekker, New York.

[6] J. ĩmija, M.J. Maáachowski, J. ZieliĚski, M. Wacáawek, K. ĝciē̄ka, 2006, Organic materials for electronics, Chemistry-Didactics-Ecology-Metrology 11/1-2 69-80 (in Polish).

[7] Wang, M. and Chuang, E. 20 July 2007. 'Bright future for flexible displays', Digitimes.

[8] J. Godlewski, M. Obarowska, 2007, Organic light emitting devices, Opto-Electronics 15/4 179-183.

[9] T. Urabe, 2008, the outstanding potential of OLED displays for TV applications, SID Society for Information Display 24/9 14-17.

[10] M. G. Helander, Z. B. Wang, J. Qiu, M. T. Greiner, D. P.Puzzo, Z. W. Liu, and Z. H. Lu,2011 ,Science332, 944.

[11] K. S. Choi, Y. Park, K.-C. Kwon, J. Kim, C. K. Kim, S. Y.Kim, K. Hong, and J.-L. Lee, J. Electrochem. 201, Soc.158, J231. 